\title{
DESTINY OF DESTINATIONS: CAN TDM HELP?
}

\section{Zsuzsanna BACSI, PhD, associate professor}

University of Pannonia, Georgikon Faculty

Address: $\quad$ H-8360 Keszthely, Deák F. u. 16,

Phone: +36-83-545-366

E-mail: $\quad$ h5519bac@ella.hu

Ernő KOVÁCS, PhD, associate professor

University of Pannonia, Georgikon Faculty

Address: $\quad$ H-8360 Keszthely, Deák F. u. 16,

Phone: +36-83-545-120

E-mail: h12725kov@ella.hu

Zsuzsanna LÖKE, PhD, assistant professor

University of Pannonia, Georgikon Faculty

Address: $\quad$ H-8360 Keszthely, Deák F. u. 16,

Phone: +36-83-545-162

E-mail: $\quad$ loke@georgikon.hu

\section{Krisztián HORVÁTH, chief executive}

H\&H Minőség Tanácsadó Bt.

Address : $\quad$ H-8360 Keszthely, Toldi út 16/B.,

E-mail: $\quad$ horvat.krisztian@gmail.com

Acknowledgement: The research presented in the paper has been co-financed by the European Union through the Hungary-Croatia IPA Cross-Border Cooperation Programme. Project no: HUHR/1101/2.1.3/0006, Project Acronym: 'Health \&Rural Tourism DM Model. 


\title{
DESTINY OF DESTINATIONS: CAN TDM HELP?
}

Keywords: health tourism, tourism destination management, survey, Western Hungary

\begin{abstract}
:
Tourism destination management (TDM) is a popular catchword of current tourism research. A research, co-financed by the European Union through the Hungary-Croatia IPA Cross-border Co-operation Programme, within the project 'Health \&Rural Tourism DM Model' (project no.: HUHR/1101/2.1.3/0006), was carried out in 2013 to analyse the specialities of TDM in health tourism destinations, the physical and human resources of such destinations, aspects of sustainability and competitiveness, the main factors of success. Primary data were collected by surveys and interviews carried out in six spa towns of Western Hungary. The main findings indicated, that the major natural natural endowment is medicinal water in the research area, tourism infrastructure and superstructure are sufficient, although the range of services, and marketing of health tourism services should be improved. Destination management organisations perform least efficiently in attracting investors. The attitudes of stakeholders of the tourism sector towards the idea of TDM differ, while in less successful destinations they are more inclined to cooperate this way, they are rather reluctant to do so in successful destinations. Assessing the traits of tourism service providers, the natural assets, the local community and the targeted tourist segments a general model of health tourism destinations is outlined by the four componenets of the well-known VICE model.
\end{abstract}

\section{INTRODUCTION}

The present paper describes results of a research project that analysed the practical implementation of tourism destination management (TDM) in health tourism destinations in general, and such destinations in Western Hungary, in particular, with the aim of identifying the key components of TDM for health tourism destinations. The project was co-financed by the European Union through the Hungary-Croatia IPA Cross-border Cooperation Programme (project title: Health \&Rural Tourism DM Model, project no.: HUHR/1101/2.1.3/0006). The motivation of the research was to find the core components of health tourism destination management, considering the fact, that the core product they offer is a complex experience, which incorporates attractions and entertainment, accommodation and food, accessibility and local transport, hospitality and friendly attitude of local people. Such a complex supply requires the close cooperation of businesses working in the tourism industry, the municipalities and public authorities as well as local inhabitants. The special attractions of the area should be treated with great care to guarantee sustainability, while development plans should pay attention to the interests of all stakeholders, including tourists.

As the success of these tourism destinations depend on many stakeholders, their cooperation requires conscious, target-oriented approach, and the purpose of tourism destination management organisations is to initiate and manage this cooperation. General 
aspects of tourism destination management organisations have been well researched in the relevant literature but little is known about their specific traits in health tourism destinations. The objective of the present paper is to present the results of a research targeted at these destinations, to define their key functions, activities and composition.

The paper summarises the main concepts of destination competitiveness and sustainability and the theory of destination management, then it describes briefly the health tourism destinations of the project area, Zala, Somogy and Baranya counties. Then the findings of a research carried out in six health tourism destinations are presented and assessed. Finally, based on these findings, conclusions are drawn about the specialities of health tourism destinations relying on the cooperation of all stakeholders: tourism service providers, local community and public sector, the environment and the targeted tourists.

\section{REVIEW OF THE RELEVANT LITERATURE}

\section{Competitive and sustainable tourism destinations}

Tourism supply is a complex concept composed of the key attractions (e.g. natural endowments), the travel and transport system and other necessary infrastructure, the providers of accommodation, food and entertainments (i.e. superstructure), and the presence of security, hygiene, and the hospitality of the local population (Lengyel, 1994/2004).

The destination is therefore the location that is capable of offering a complex tourism product with all the above components: accommodation, food and beverage services and the facilities to access the attractions, including travel and transport. A crucial component of success is the marketing of the destination to reach the targeted tourist segments (Lengyel, 2008).

A location is required to provide a complex network of all the above facilities and services in order to offer a complex experience which the present-day tourists look for (Pike, 2008). The complexity of the components requires the cooperation of the service providers, which a well-structured management organisaton can efficiently initiate and manage. (Auber et al., 2011).

As the UNWTO (2007, p.1) defines: 'A local tourism destination is a physical space in which a tourist spends at least one overnight. It includes tourism products such as support services and attractions and tourist resources within one day's return travel time. It has physical and administrative boundaries defining its management, and images and 
perceptions defining its market competitiveness. Local destinations incorporate various stakeholders often including a host community, and can nest and network to form larger destinations.'

Tourism industry is characterised by the strong competition among destinations, therefore destination competitiveness is one of the major areas of tourism research.

Pike (2008) emphasises the multidimensional character of tourism destination competitiveness. This includes sustainability, prices, management, reactions to competition, the tourism product itself, and its perception by tourists, accessibility of the destination and public transport, integrated quality management, regional positioning, and marketing the competitive destination for the future. As Pike (2008) describes, there is no generally accepted causal model for destination competitiveness, but the idea is generally accepted, that such a model should incorporate economic, social, cultural and environmental aspects of the destination. Another problem in creating such a causal model is, that there is no generally accepted set of indicators to accurately measure how successful a destination is (Papp, 2012).

The principal features of a competitive tourism destination are (Ritchie and Crouch, 2003):

- to increase tourism expenditure,

- to increasingly attract visitors

- to provide them with satisfying, memorable experiences, and

- to do so in a profitable way, and

- to enhance the well-being of destination residents and

- to preserve the natural capital of the destination for future generations.

Ritchie és Crouch (2003) outlined a model of destination competitiveness, relying on Porter's diamond model of competitiveness (Porter, 1990). The following components have been included: (i) core resources and attractions (ii) supporting factors and resources (iii) destination management (iv) destination policy, planning and development (v) qualifying and amplifying determinants. Similar models have been developed by others (Enright-Newton, 2004).

Besides the general purpose models other approaches focus on specific aspects of competitiveness. The model by Dwyer and Kim (2004) measures the price competition among destinations, stressing some aspects not included in the Ritchie-Crouch model: the 
distinction between primary natural, environmental endowments, and purpose-built tourism facilities and developments, as well as the importance of demand in destination competitiveness.

As it was described above, a destination is competitive if tourists regularly choose it to visit, are willing to return to it, and recommend it to others. A destination cannot be successful in the long run if the current success is based on the exploitation of its endowments, therefore sustainability is necessary for long-term competitiveness. Exploitation of ecologically sensitive destinations, overcrowding, mass tourism and the overuse of infrastructural capacities may quickly decrease the attractiveness of a destination for the future.

The core principle of sustainability is to limit the visitors' impact on the destination at a manageable level, serving the true present and future interests of all stakeholders, local populaton and tourists (Climpson, 2008). Climpson summarises the aspects of sustainable development of tourism destinations in the well-known VICE model. The model contains four components: V (visitors) means tourists coming to the area, I (industry) stands for the service providers and businesses involved in the tourism sector, $\mathrm{C}$ (community) represents the local community, the population living in the area and experiencing the benefits and harms caused by tourism developments, and influencing the tourism experience offered to visitors. E (environment) includes the natural and the built environment that is available for the visitors, the industry and the local community, and this environment keeps changing in response to the activities of these groups. The VICE model emphasises the dynamic interactions of these four components (Climpson, 2008).

Sustainability of tourism means that its interests do not conflict with the interests of any of the above four components. To guarantee this, tourism management should keep visitor flows beneficial to the present and future state of the destination community, economy, and environment (Lengyel, 2008). This requires (i) satisfaction and fulfilling experiences for the tourist; (ii) growing economy and prospering tourism -businesses; (iii) enrichment of the community and its culture; (iv) protection for the natural and built environment.

\section{The concept of tourism destination management}

To guarantee sustainability and competitiveness the cooperation of many stakeholders, and the thorough knowledge of the system of tourism are needed. To achieve these aims, an efficient arrangement may be to establish an organisation for managing and coordinating the relevant tasks, and involving all the stakeholders in these activities. The 
organisation can generate cooperation, so that decisions will be made involving all stakeholders. A bottom-up approach involving the stakeholders, professionalism, partnership, and financial resources for independent action are all needed (Lengyel, 2008). Permanent success cannot be hoped for without professional skills and knowledge, so a TDM organisation needs an operative unit for managing the day-to-day practical work, with well-trained staff led by a professional manager. This operational unit should professionally implement the organisations's decisions.

The bottom-up approach is justified by the fact, that in practice, the aspects of sustainable competitiveness, as defined by the VICE model, are handled at the local level, by the conscious activities of local stakeholders: accommodation providers, owners of restaurants and pubs, providers of entertainments and programmes, and the local population. The process of building a TDM organisation should, however, be supported and encouraged from above, providing support from the national government (Lengyel, 2008).

Ritchie and Crouch (2003) summarised the organisational issues and functions of destination management, declaring the most important components as:

- marketing, marketing, identification of targeted markets, the positioning of the destination, market segmentation, the design of logos and promotional material,

- building a destination image, branding the destination, evalulating brand efficiency,

- monitoring the activities, search for information and research,

- the attraction of private capital for financing tourism-related developments,

- human resource management, visitor management and the responsible stewardship over natural resources.

For efficient destination management the cyclical flow of a series of steps should be followed, which lead to permanent sustainable development in the destination. The process is divided into 8 separate steps, which are complementary and are closely related to each other (Nyírádi-Semsei, 2007):

- Searching for attractions (values of the area).

- Development of attractions towards creating tourism products.

- Building tourism products and product groups.

- Embedding the developed tourism products into the destination.

- Introducing the destinations and the embedded tourism products to the market. 
- Selling the products.

- Providing perfect experience for visitors.

- Keeping the satisfied customers as visitors for the future.

The success of the tourism industry in the destination depends mainly on the careful planning of the whole process and its individual steps, and to manage the process according to the plans.

Figure 1 The operation of destination management organisations

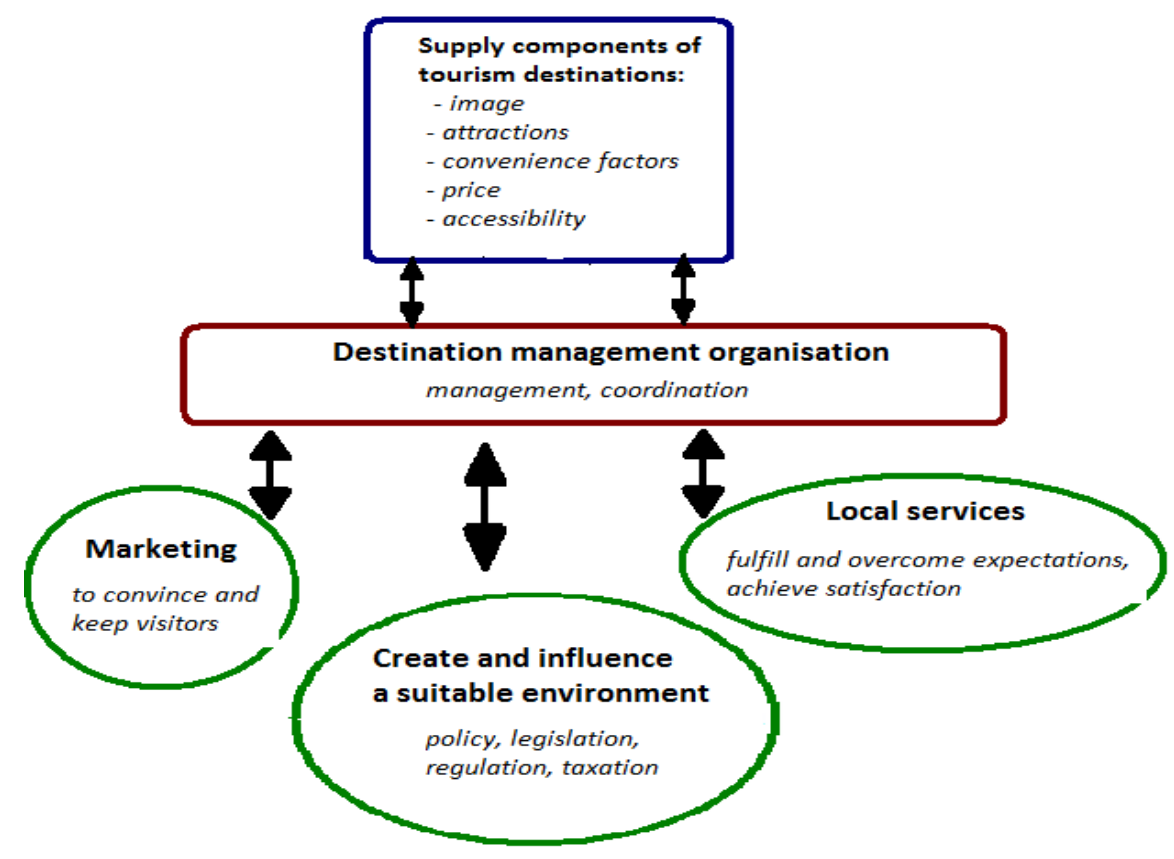

Source: Panyor et. al. 2011 (page 15).

Destination management organisations may be created by the public sector or solely by private actors, or they may be established as the result of joint action of public and private partners. Because the approach, goal structure and operation logic of the public sector considerably differs from the private sector, it is recommended to include both sectors in destination management. However, careful considerations are needed to decide about the most suitable organisational form and involved actors at various destination management levels to ensure the most efficient operation and the interests of the destination community (Panyor et al, 2011). 
When designing a destination management model for health tourism destinations the core components of such destinations should be identified. Regarding the environmental aspects of such a model the following natural resources should be considered.

Below $70 \%$ of the total territory of Hungary thermal water resources are found, therefore in international comparison, Hungary is the fifth richest country regarding thermal water resources. In Hungary altogether 385 settlements own a thermal or a medicinal spa. The medicinal waters are grouped into various categories by their location and content - of sodium chloride, iodine, bromide, calcined lime, sulphur, carbon dioxide, radon and besides the most frequent balneotherapy use they are also utilised for drinking and for inhalation therapies. Besides healing waters other natural healing endowments include medicinal caves where the unique microclimatic conditions and the quiet environment serve as healing factors. Another healing resource is medicinal mud: Hungary possesses 5 recognised natural healing muds (Kolopi, Marosi, Lake Hévíz, Hajdúszoboszló Town Spa and the "Georgikon" healing mud in Alsópáhok). Another important healing factor is the medicinal gas in Mátraderecske, where due to post-vulcanic activity $\mathrm{CO}^{2}$ evaporation is experienced, and following the acknowledgement as medicinal gas in 1999 a medical centre was established for applying the gas for treating varicosis, vein disorders in limbs, as well as those suffering vein disorders due to hypo- or hyperglycemic problems. In wellness tourism the existence of natural healing factors is not a precondition, but is considered a competitive advantage. In Hungary the underground hot water resources are so rich that though the international terminology considers waters above $20^{\circ} \mathrm{C}$ as thermal waters, in Hungary this term is applied only to waters above $30^{\circ} \mathrm{C}$ (Kovács et al., 2011). The definite, crucial health tourism endowments of the Croatia-Hungary border region are medicinal and thermal waters, as there is only one medicinal cave in the area, in Abaliget, county Baranya. Recognised medicinal mud is found in county Zala, in Hévíz (Hévíz medicinal mud), and Alsópáhok (Georgikon medicinal mud). Although in the Mecsek hills climatic conditions are utilised in sanatoria at climatic resorts, there are no climatic spa resorts or mofettas in the area. However, the area is very rich and varied regarding water resources. In county Zala there are 10 settlements having medicinal or thermal spas or outdoor pools, in Somogy 13 such settlements exist and in Baranya 8 more are found (Kovács et al., 2011).

Within the project area county Zala possesses exceptional health tourism resources. The website Wikitravel describes in detail the natural endowments and other touristic 
attractions of county Zala. The page pays special attention to settlements and spas that possess the most important natural healing resources - medicinal and thermal waters.

The described spas are the following (Wikitravel, Zala megye, 2013):

- Hévíz: the thermal water of Lake Hévíz is a healing water containing calcium, and magnesium, hydrogen carbonate, sulphur and low concentration of radon.

- Zalakaros: internationally renowned spa, its medicinal water comes from a spring 2000 $\mathrm{m}$ below the surface, of $96 \mathrm{C}^{\circ}$ temperature, the composition of the water is special: the healing water contains sodium chloride and hydrogen-carbonate, with unique iodicbromous, sulphurous and fluoric content.

- Lenti: The spa was built ont he 40 degree thermal spring found in 1970. The medicinal water of Lenti is renowned throoughout Europe, a 40000 year-old hydrogen carbonated water suitable for treating locomotor diseases, joint disorders, spinal and dorsal problems.

- Kehidakustány: Registered qualified medicinal water of calcium, magnesium and hydrogen carbonate content, classified as sulphuric medicinal water, with no radon content.

- Two significant thermal spas of the county are the Aquacity Zalaegerszeg Fun and Water Slide Park and Thermal Spa in Zalaegerszeg, and the Szent Gróth Thermal Spa in Zalaszentgrót.

\section{OBJECTIVES AND METHODS}

A questionnaire-based survey was carried out, in three counties of Western Hungary: Zala, Somogy and Baranya.

The destinations involved in the sample were selected in the following way: the data published by the Central Statistical Office of Hungary (KSH, 2013) lists altogether 19 settlements in the three researched counties, that are involved in health tourism, 18 of which posess a spa with medicinal water as the healing resource. Therefore the key healing resource was assumed to be the medicinal water in the region.

The selection of the destinations was done by the indicators of tourism demand (measured by guest nights in the destination) and tourism supply (measured by available accommodation per 1000 inhabitants). The share of the counties in the tourism sector of the project area was measured by the mean values of the above supply and demand indicators (Tab. 1). 
Table 1 Supply-side and demand-side indicators of settlements involved in medical tourism

\begin{tabular}{|c|c|c|c|c|c|}
\hline & $\begin{array}{c}\text { Number of } \\
\text { involved } \\
\text { towns, } \\
\text { villages }\end{array}$ & $\begin{array}{c}\text { Supply-side } \\
\text { indicator: } \\
\text { accommodation } \\
\text { per } 1000 \\
\text { inhabitants }\end{array}$ & $\begin{array}{c}\text { Demand-side } \\
\text { indicator: Guest } \\
\text { nights in } \\
\text { commercial } \\
\text { accommodations }\end{array}$ & $\begin{array}{c}\text { Mean of } \\
\text { supply-side } \\
\text { and } \\
\text { demand- } \\
\text { side } \\
\text { indicators }\end{array}$ & $\begin{array}{c}\text { The share } \\
\text { of the } \\
\text { county in } \\
\text { the survey } \\
\text { sample }\end{array}$ \\
\hline Zala $\%$ & $26,3 \%$ & $81,8 \%$ & $59,6 \%$ & $70,7 \%$ & $\mathbf{7 0 \%}$ \\
\hline Somogy $\%$ & $47,4 \%$ & $13,5 \%$ & $25,9 \%$ & $19,7 \%$ & $\mathbf{2 0 \%}$ \\
\hline Baranya $\%$ & $26,3 \%$ & $4,7 \%$ & $14,5 \%$ & $9,6 \%$ & $\mathbf{1 0 \%}$ \\
\hline Total, $\%$ & $100,0 \%$ & $100,0 \%$ & $100,0 \%$ & $100,0 \%$ & $\mathbf{1 0 0 , 0 \%}$ \\
\hline
\end{tabular}

Source:Authors' own construction based on KSH, 2013

Therefore $70 \%$ of the questionnaires were surveyed in Zala, $20 \%$ in Somogy, and $10 \%$ in Baranya. The destinations were selected by randomly, one-third, i.e. 6 destinations were chosen of the 19 settlements: 4 (67\%) in county Zala, one in Somogy and one in Baranya $(16,7 \%$ each), to include at least one settlement from each county. Marcali in Somogy, and Siklós in Baranya were randomly selected, the 4 settlements in county Zala (Hévíz, Zalakaros, Kehidakustány, Lenti) were selected of the 5 settlements listed by KSH (2013), leaving out the least significant settlement, Alsópáhok.

The composition of the sample was determined relying on a survey by Kontaktia (2011) that assessed the composition of 26 TDM organisations in Hungary. This study shows, that accommodation and food service providers represent an approximate $75 \%$ of all businesses involved in TDM organisations. Therefore we constructed our sample having 3-times as many accommodation and food service providers as other enterprises. There are 1449 accommodation and food service providers in the 6 sampled settlements by KSH (2013). $3 \%$ of them were included in the sample, therefore 43 such enterprises were selected. The number of other businesses was one third of this number, i.e. 12. As the key tourism attraction in the destinations is the spa, we planned to involve all spas (6) in the sample (ultimately 5 remained, as one spa was unable to participate in the research). As the municipalities are important generators of TDM cooperation, naturally the municipalities of the 6 selected destinations were also involved in the survey (ultimately, Lenti was not able to participate, so we questioned only 5 municipalities). Representatives of TDM organisations, and Tourinform organisations were also included ( 1 or 2 participants, in 
each settlement). This left us with a sample of 75 respondents. The sample was complemented by 25 local inhabitants - though they are not key actors of the TDM organisation, their attitudes towards tourists are important factors in the appeal of the destination. Finally the sample was divided by destinations: of the 70 questionnaires of county Zala 20 questionnaires were taken to the larger destinations: Hévíz, Kehidakustány and Zalakaros, the remaining 10 in Lenti. Then 20 questionnaires were taken to Marcali, and 10 questionnaires to Siklós to keep the proportions of Somogy and Baranya at 20 and $10 \%$ respectively. Tab. 2 shows the final composition of the sample.

Table 2 Respondents by settlements

\begin{tabular}{|c|c|c|c|c|c|c|c|c|c|}
\hline Job status & \multirow[t]{2}{*}{ Total } & \multirow[b]{2}{*}{$\begin{array}{c}\text { Local } \\
\text { inhabitants }\end{array}$} & \multicolumn{4}{|c|}{ Tourism service providers } & \multicolumn{3}{|c|}{ Public sector } \\
\hline Town, village & & & $\begin{array}{l}\text { Accommodation } \\
\text { and food service }\end{array}$ & Spa & $\begin{array}{l}\text { Other } \\
\text { services }\end{array}$ & Total & $\begin{array}{c}\text { Municip- } \\
\text { ality. }\end{array}$ & $\begin{array}{l}\text { Tour- } \\
\text { inform, } \\
\text { TDMO. }\end{array}$ & Total \\
\hline 1:Hévíz* & 19 & 5 & 6 & 1 & 4 & 11 & 1 & 2 & 3 \\
\hline 2:Kehidakustány & 20 & 5 & 11 & 1 & 0 & 12 & 1 & 2 & 3 \\
\hline 3:Lenti* & 11 & 5 & 2 & 1 & 2 & 5 & 0 & 1 & 1 \\
\hline 4:Zalakaros & 20 & 5 & 11 & 1 & 0 & 12 & 1 & 2 & 3 \\
\hline 5:Marcali & 20 & 5 & 7 & 1 & 4 & 12 & 1 & 2 & 3 \\
\hline 6: Siklós & 10 & 0 & 6 & 0 & 2 & 8 & 1 & 1 & 2 \\
\hline Total & 100 & 25 & 43 & 5 & 12 & 60 & 5 & 10 & 15 \\
\hline
\end{tabular}

*: Due to respondents' reluctance to respond in Héviz, Hévíz participated only with 19 respondents, and an additional questionnaire was taken in Lenti instead

The respondents of the sample were grouped by their job status: local inhabitants made up $25 \%$ of the sample, tourism service providers (i.e. the spa leader, the accommodation and food service providers, other service providers) represented $60 \%$, nd actors of the public sector (employees of municipalities, and of Tourinform bureaus or TDM organisations) 15\%. The locations of the survey are indicated in Fig. 2 below. 
Figure 2 The area of the survey

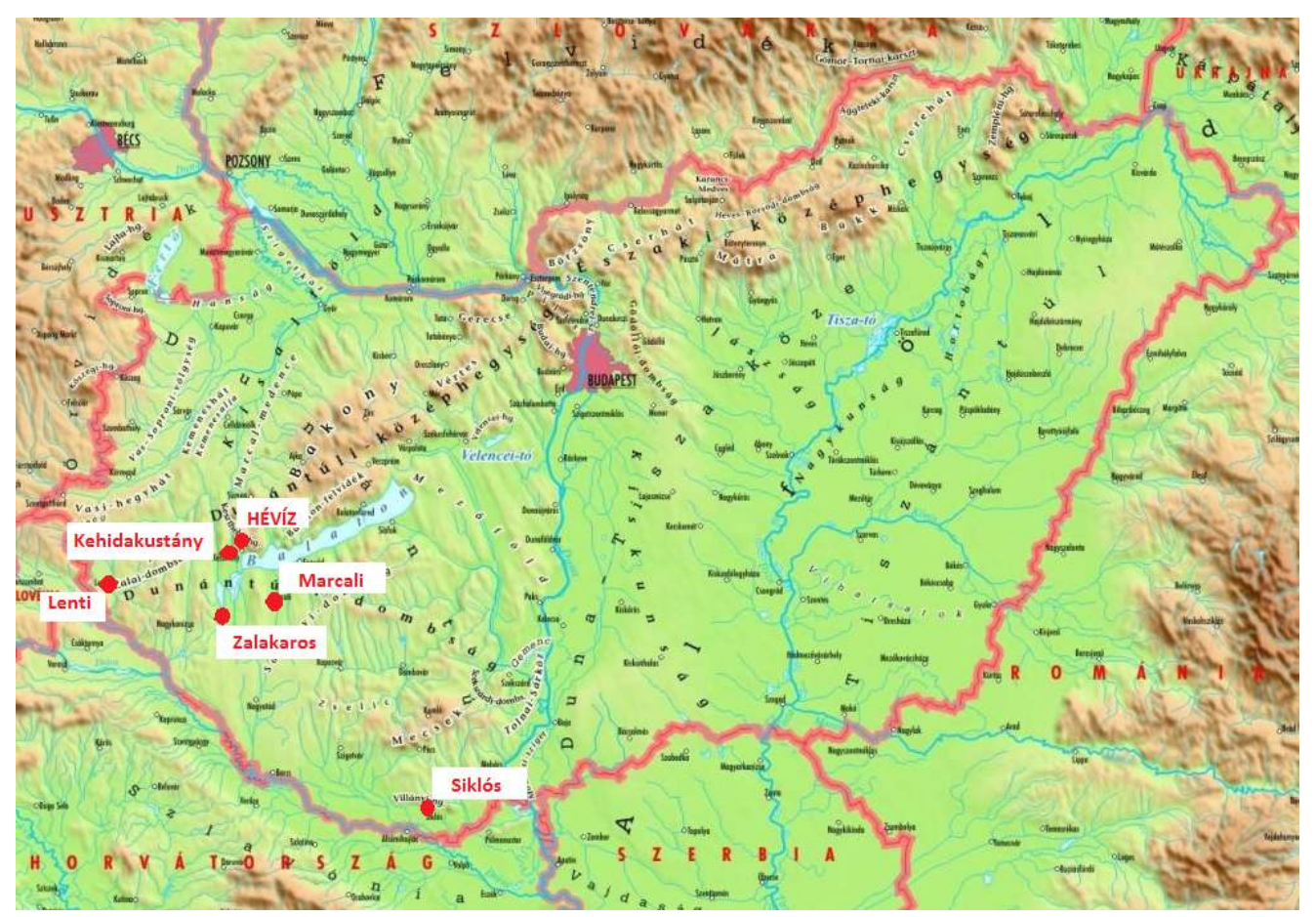

Tab. 3 gives the tourism-related statistical data of the sampled destinations.

Table 3 The statistical data of the surveyed towns and villages

\begin{tabular}{|c|c|c|c|c|c|c|c|}
\hline & $\begin{array}{l}\text { Populatio } \\
\text { n (person) }\end{array}$ & $\begin{array}{l}\text { Populatio } \\
\text { n per } 100 \\
\text { houses } \\
\text { and } \\
\text { second } \\
\text { homes } \\
\text { used } \\
\text { perm- } \\
\text { anently }\end{array}$ & $\begin{array}{c}\text { Total } \\
\text { places in } \\
\text { commerc } \\
\text {-ial and } \\
\text { non- } \\
\text { com- } \\
\text { mercial } \\
\text { accomm- } \\
\text { odations }\end{array}$ & $\begin{array}{l}\text { Food } \\
\text { service } \\
\text { provider } \\
\text { s }\end{array}$ & $\begin{array}{l}\text { Commerc } \\
\text { ial } \\
\text { accomm- } \\
\text { odation } \\
\text { places } \\
\text { per } 1000 \\
\text { inhabit- } \\
\text { ants }\end{array}$ & $\begin{array}{c}\text { Other } \\
\text { accomm- } \\
\text { odation } \\
\text { places } \\
\text { per } 1000 \\
\text { inhabit- } \\
\text { ants }\end{array}$ & $\begin{array}{c}\text { Guest } \\
\text { nights } \\
\text { per } \\
\text { inhabit- } \\
\text { ants in } \\
\text { all } \\
\text { accomm- } \\
\text { odations }\end{array}$ \\
\hline Hévíz & 4715 & 224 & 9181 & 151 & 1310 & 636.90 & 228.00 \\
\hline Kehidakustány & 1189 & 265 & 1952 & 22 & 650 & 991.59 & 41.74 \\
\hline Lenti & 7940 & 247 & 1297 & 71 & 99 & 63.85 & 4.14 \\
\hline Zalakaros & 1756 & 245 & 7596 & 84 & 2312 & 2013.67 & 259.58 \\
\hline Marcali & 11736 & 242 & 180 & 44 & 5 & 10.22 & 0.30 \\
\hline Siklós & 9574 & 251 & 187 & 63 & 6 & 13.47 & 0.23 \\
\hline $\begin{array}{l}\text { All settlements (137) } \\
\text { in health tourism, } \\
\text { Hungary }\end{array}$ & 4550246 & 230 & 293359 & 30607 & 45 & 2421.24 & 516.56 \\
\hline Hungary total & 9937628 & 248 & 555451 & 55953 & 34 & 48.14 & 5.53 \\
\hline
\end{tabular}

Source: KSH, 2013

The survey was made in September and October 2013. The data were processed by MSEXCEL 2010, and by the OpenStat statistics package (Miller, 2004, 2013). Variables were 
analysed by simple descriptive statistics. Most of the variables of the questionnaire were nominal variables, which were recoded to integer values. The recoded values were analysed by contingency analysis, relationships between variables were tested by $\mathrm{Chi}^{2}$-test, and Cramér's V statistics. The relationships between numerical variables were tested by analysis of variance (ANOVA) and by regression and correlation analysis. The significance tests were done at $5 \%$ error probability.

\section{RESULTS}

The importance of health tourism in the tourism sector: capacities and demand in Hungary Health tourism destinations have shown considerable progress in the recent years in Hungary. The main indicators of health tourism by the published statistics of KSH show, that this is one of the most important sectors of tourims in Hungary. Assessing the supply side more than $25 \%$ of all accommodation capacities (rooms and beds in 2010 and in 2012) are found in health and wellness hotels (Tab. 4). Its role is even more important considering the demand side and profitability: $36-37 \%$ of the sales receipts of hotels is received in health and wellness hotels. The average sales receipts per hotel are twice as high in health and wellness hotel as in hotels in general. Health hotels have achieved 2.8 times more than the average in 2010, and this figure has growm to 4 times the average in 2012.The average sales receipts of wellness hotels ar also higher that the average, by 1.4 to 1.6 times. This higher income is achieved while the average length of stay in wellness hotels is the same as in general hotels (2.5 days), and it is $48 \%$ higher (3.7 days) in health hotels (Tab. 5).

Table 4 Key data about health and wellness tourism in Hungary, 2010-2012

\begin{tabular}{|c|c|c|c|c|c|c|c|c|}
\hline & \multicolumn{2}{|c|}{ Hotels (all) } & \multicolumn{2}{|c|}{ Health hotels } & \multicolumn{2}{|c|}{ Wellness hotels } & \multicolumn{2}{|c|}{$\begin{array}{l}\text { Health \& wellness } \\
\text { hotels, as } \% \text { of all }\end{array}$} \\
\hline Year & 2010 & 2012 & 2010 & 2012 & 2010 & 2012 & 2010 & 2012 \\
\hline Units & 900 & 997 & 62 & 30 & 107 & 164 & $18.8 \%$ & $19.5 \%$ \\
\hline Rrooms & 54308 & 58214 & 7211 & 4578 & 7384 & 11161 & $26.9 \%$ & $27.0 \%$ \\
\hline Places (beds) & $\begin{array}{l}123 \\
518\end{array}$ & 138729 & 14953 & 10357 & 17749 & 27272 & $26.5 \%$ & $27.1 \%$ \\
\hline $\begin{array}{l}\text { Gross sales receipts, } \\
\text { billion HUF }\end{array}$ & 206.9 & 242.2 & 40.0 & 29.011 & 35.3 & 62.0 & $36.4 \%$ & $37.6 \%$ \\
\hline $\begin{array}{l}\text { Sales receipts per } \\
\text { hotel, million } H U F\end{array}$ & 229.9 & 242.9 & 645.1 & 970.0 & 327.1 & 378.0 & $193.8 \%$ & $193.3 \%$ \\
\hline
\end{tabular}

Source: KSH 
Kovács et al. (2011) and Boros et al. (2012) assess the numbers of health and wellness hotels in the 11 -year period of 1999-2010, and state that the number of health hotels increased continuously up to 2007 , followed by a slight decrease, while the number of wellness hotels showed dynamic growth throughout the whole period. The data by KSH (2013) showed that the trend has continued in the last two years, too (Fig. 3). While the number of wellness hotels increased eleven times the initial value in the 8 years from 2004 to 2013 (the average annual growth rate being 37\%), the number of health hotels decreased by $48 \%$ (an average annual decrease of $5 \%$ ).

Figure $3 \quad$ Numbers of health and wellness hotels between 1999 and 2012

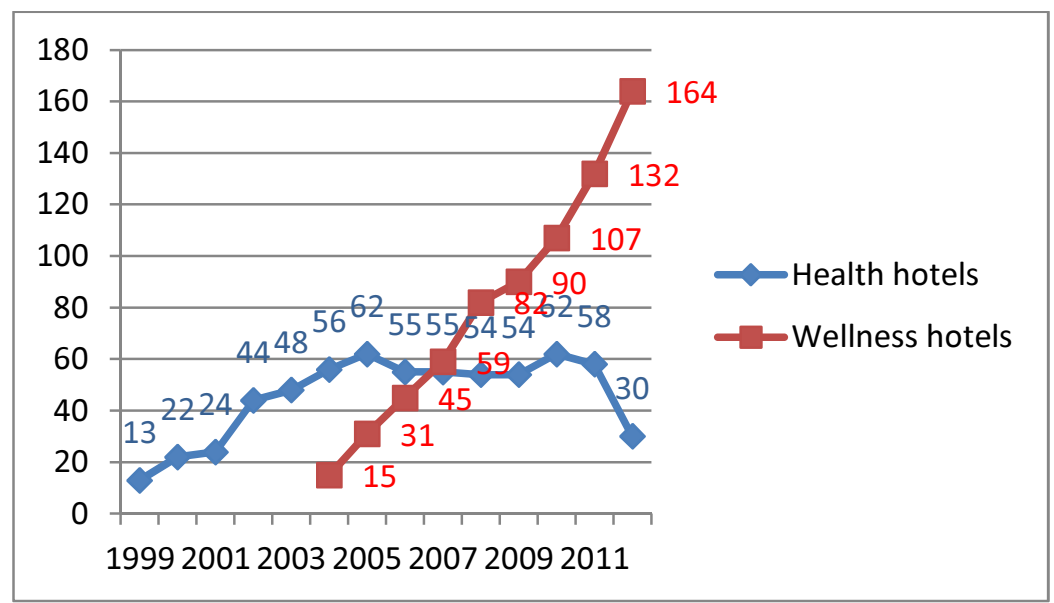

Source: Boros et al. (2012), KSH(2013), Kovács et al.(2011)

Trends of visitor numbers are characterised by the following features (Boros et al.,2012).

Regarding guest nights health hotels were ahead of wellness hotels up to 2010, and the trend started to turn from 2011. The total number of guest nights in wellness hotels has kept rising during the last 8 years, while health hotels show stagnation, and even a slight, but stable decrease since 2008 .

The average length of stay in hotels in Hungary is rather low (only 2.7 to 2.5 days in the period 2005 to 2012), and the average length of stay in all accommodations is only slightly higher. At the same time, the figure for health hotels is higher by one full day (but it is not more than 3.7 - 3.4 days). The average length of stay in wellness hotels is 2.5-2.4 days. In 2012 the stay in health hotels rose to 3.7 days, the decreasing trend turned upward, and a slight increase was measured in wellness hotels, too. The length of stay in health hotels has been higher than the average of all commercial acccommodations in the years 2005 to 2012 , the same figure for wellness hotels is somewhat lower, but it also started to rise after 2008 , reaching the level 2.5 days, i.e. that of the general hotel average for the country (Tab. $5)$. 
Table 5 Data about visitor numbers in health tourism, 2005-2012

\begin{tabular}{|l|r|r|r|r|r|r|r|r|}
\hline $\begin{array}{l}\text { Number of visitors, } \\
\text { 1000 persons }\end{array}$ & $\mathbf{2 0 0 5}$ & $\mathbf{2 0 0 6}$ & $\mathbf{2 0 0 7}$ & $\mathbf{2 0 0 8}$ & $\mathbf{2 0 0 9}$ & $\mathbf{2 0 1 0}$ & $\mathbf{2 0 1 1}$ & $\mathbf{2 0 1 2}$ \\
\hline Health hotels & 727 & $\mathbf{7 2 9}$ & 763 & 766 & 683 & 751 & 646 & 501 \\
\hline Wellness hotels & 283 & 508 & 602 & 715 & 714 & 917 & 1211 & 1506 \\
\hline Health hotels & 2721 & 2653 & 2733 & 2695 & 2453 & 2571 & 2201 & 1829 \\
\hline Wellness hotels & 702 & 1255 & 1447 & 1660 & 1673 & 2221 & 2908 & 3778 \\
\hline All hotels & & & & & & & 15372 & 16624 \\
\hline Average length of & & & & & & & & \\
stay, days & $\mathbf{2 0 0 5}$ & $\mathbf{2 0 0 6}$ & $\mathbf{2 0 0 7}$ & $\mathbf{2 0 0 8}$ & $\mathbf{2 0 0 9}$ & $\mathbf{2 0 1 0}$ & $\mathbf{2 0 1 1}$ & $\mathbf{2 0 1 2}$ \\
\hline Health hotels & 3.7 & 3.6 & 3.6 & 3.5 & 3.6 & 3.4 & 3.4 & 3.7 \\
\hline Wellness hotels & 2.5 & 2.5 & 2.4 & 2.3 & 2.3 & 2.4 & 2.4 & 2.5 \\
\hline All hotels & 2.7 & 2.7 & 2.6 & 2.5 & 2.5 & 2.5 & 2.5 & 2.5 \\
\hline All accommodations & 2.8 & 2.7 & 2.7 & 2.6 & 2.6 & 2.6 & 2.6 & 2.6 \\
\hline Receipts, billion HUF & $\mathbf{2 0 0 5}$ & $\mathbf{2 0 0 6}$ & $\mathbf{2 0 0 7}$ & $\mathbf{2 0 0 8}$ & $\mathbf{2 0 0 9}$ & $\mathbf{2 0 1 0}$ & $\mathbf{2 0 1 1}$ & $\mathbf{2 0 1 2}$ \\
\hline Health hotels & & 40.2 & 42 & 41.9 & 37.9 & 40 & 32.9 & 29.1 \\
\hline Wellness hotels & & 17.7 & 21.4 & 25.2 & 26.3 & 35.2 & 45.4 & 62.0 \\
\hline All hotels & & & & & & 229.9 & 224.8 & 242.2 \\
\hline All accommodations & & - & - & - & 224.8 & 237.8 & - & 270.8 \\
\hline
\end{tabular}

Source: Boros et al.(2012), KSH (2013), Kovács et al.(2011), and Magyar Turizmus Zrt.

The sales receipts of all commercial accommodations were 224.8 billion HUF in 2009, and 237.8 billion HUF in 2010 . The health and wellness hotels received $28.6 \%$ of it in 2009 , and $31.6 \%$ in 2010 . In 2012 the total sales receipts of health hotels decreased to 29.1 billion HUF, while that of wellness hotels increased to 62 billion HUF, so the shorter length of stay was compensated by the increase in capacities, leading to rising sales revenues. The total sales revenues in all commercial accommodations were 270.8 billion HUF in this year, the share of health and wellness hotels being $34 \%$. These figures show that the role and weight of health tourism has increased within domestic tourism.

As the data from KSH show, the 10 most popular towns and cities of Hungary included 5 spa towns in 2012, of which two (Hévíz and Zalakaros) are located in county Zala. The situation was very similar in the former years, too (Tab. 6).

Table 6 The most popular destinations in Hungary in 2012

\begin{tabular}{|c|c|c|}
\hline Domestic tourists & Foreign tourists & All tourists \\
\hline 1. Budapest (890) & 1. Budapest (6523) & 1. Budapest (743) \\
2. Hajdúszoboszló (461) & 2. Hévíz (671) & 2. Hévíz (1005) \\
3. Siófok (428) & 3. Bük (368) & 3. Hajdúszoboszló (713) \\
4. Hévíz (333) & 4. Sárvár (273) & 4. Bük (635) \\
5. Zalakaros (283) & 5. Hajdúszoboszló (251) & 5. Siófok (625) \\
& & \\
\hline
\end{tabular}


Table 6 (continued)

\begin{tabular}{|c|c|c|}
\hline 6. Sopron (277) & 6. Balatonfüred (232) & 6. Balatonfüred (480) \\
7. Gyula (269) & 7. Györ (200) & 7. Sárvár (453) \\
8. Bük (267) & 8. Siófok (197) & 8. Zalakaros (403) \\
9. Balatonfüred (248) & 9. Zalakaros (120) & 9. Sopron (369) \\
10. Eger (215) & 10. Sopron (92) & 10. Győr (358) \\
\hline
\end{tabular}

Note: the figures in parentheses give the number of guest nights spent in the destination in thousands. Source: KSH, 2013

\section{Components of the VICE model: Survey findings for health tourism destinations}

\section{E: Environment}

The respondents consider medicinal and thermal water the main natural attraction their home town or village. They also mentioned the pleasant natural environment, clear air, good climatic characteristics, and the rich flora of the region, but at much lower rates. The attitude towards natural endowments was mainly positive, two-thirds of the responders said that the natural resource should be protected, and they were very proud of the resource, or stressed the importance of sustainability in utilising the resource. Unfortunately one third of the respondents think that the resource is used without care, or even exploited excessively without appreciating its true value. Two-thirds of the respondents gave positive answers to the question in every settlement except Lenti, where only one third of the respondents indicated positive attitudes saying that the resource is protected, the people are proud of the resource, or the resource is utilised in a sustainable way (Fig. 4).

All of the employees of the municipalities, and $90 \%$ of the employees of Tourinform bureaus an TDM organisations said that the natural endowments are protected, people are proud of it, and it is utilised sustainably. The tourism service providers and local inhabitants showed more scepticism about the question, only $58 \%$ of the former and $48 \%$ of the latter group agreed to the above statements. 
Figure 4 Attitudes towards natural resource utilisation, proportions by respondents' status $(\%)$, numbers in columns give the actual number of responses.

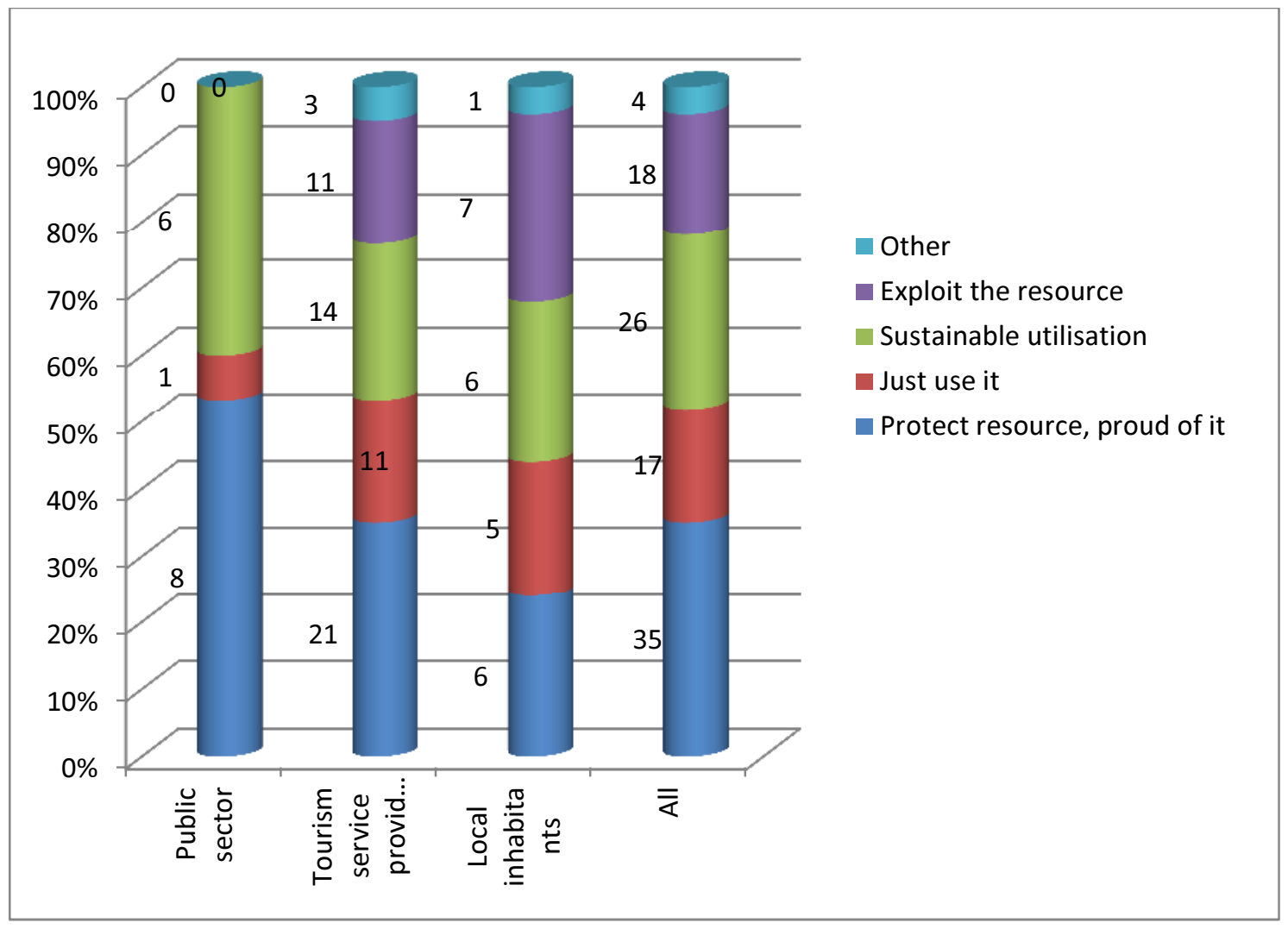

Table 7 The most important natural endowment of the place, proportions by respondents's home town/village

\begin{tabular}{|c|c|c|c|c|c|c|}
\hline \multirow[b]{2}{*}{ Town/village } & \multirow{2}{*}{$\begin{array}{c}\text { Number of } \\
\text { all } \\
\text { respondents }\end{array}$} & $\begin{array}{c}\text { 1.thermal } \\
\text { water }\end{array}$ & $\begin{array}{l}\text { 2. medicinal } \\
\text { water }\end{array}$ & $\begin{array}{l}\text { 3. clear } \\
\text { air }\end{array}$ & $\begin{array}{c}\text { 4. good } \\
\text { microclimate }\end{array}$ & 5. rich flora \\
\hline & & \multicolumn{5}{|c|}{ proportion of 'yes' answers by respondents' job status, $\%$} \\
\hline Hévíz & 19.00 & 17.14 & 26.79 & 15.79 & 20.69 & 17.24 \\
\hline Kehida & 20.00 & 24.29 & 14.29 & 15.79 & 10.34 & 10.34 \\
\hline Lenti & 11.00 & 8.57 & 12.50 & 10.53 & 10.34 & 10.34 \\
\hline Zalakaros & 20.00 & 18.57 & 30.36 & 31.58 & 34.48 & 34.48 \\
\hline Marcali & 20.00 & 17.14 & 12.50 & 15.79 & 17.24 & 24.14 \\
\hline Siklós & 10.00 & 14.29 & 3.57 & 10.53 & 6.90 & 3.45 \\
\hline Total & 100.00 & 100.00 & 100.00 & 100.00 & 100.00 & 100.00 \\
\hline \multicolumn{2}{|r|}{$\mathrm{Chi}^{2}$ test, $\mathrm{p}$} & 0.551865 & $0.003904 *$ & 0.106419 & $0.005145^{*}$ & $0.001007 *$ \\
\hline \multicolumn{2}{|c|}{$\mathrm{Chi}^{2}$-value, $\mathrm{df}=5$} & 3.98301 & 17.33626 & 9.06706 & 16.68145 & 20.49873 \\
\hline
\end{tabular}

*:significant differences between groups assuming $5 \%$ error probability

The above answers are related to the importance and role of health tourism in the specific town/village. Tab. 8 shows the coefficient of correlation which demonstrates that the 
higher guest nights per inhabitants and the more commercial accommodations per 1000 inhabitants show markedly strong relationship to the responses mentioning pride of resource and protection of resource ( 0.755 and 0.826 respectively).

Table 8 Relationship between the attitude towards the natural endowment and tourism supply / demand

\begin{tabular}{|l|c|c|}
\hline \multicolumn{1}{|c|}{ Coefficient of correlation $(\mathrm{R})$} & $\begin{array}{c}\text { Guest nights per } \\
\text { inhabitant }\end{array}$ & $\begin{array}{c}\text { Commercial accommodations } \\
\text { per 1000 inhabitants }\end{array}$ \\
\hline $\begin{array}{l}\text { Guest nights per inhabitant } \\
\text { Commercial accommodations per 1000 } \\
\text { inhabitants }\end{array}$ & $\mathbf{1 . 0 0 0}$ & $\mathbf{0 . 9 5 4}$ \\
\hline $\begin{array}{l}\text { Protect resource, proud of it, sustainable } \\
\text { utilisation }\end{array}$ & $\mathbf{0 . 9 5 4}$ & $\mathbf{1 . 0 0 0}$ \\
\hline Just use, or exploit resource & 0.437 & 0.430 \\
\hline Protect resource, proud of it & 0.116 & 0.234 \\
\hline Just use resource & 0.755 & 0.826 \\
\hline Sustainable utilisation & -0.102 & -0.057 \\
\hline Exploit resource & -0.033 & -0.088 \\
\hline
\end{tabular}

\section{$V$ : Visitors}

Respondents were asked to identify the targeted segments of tourism, most expected to the town or village, for whom the conditions are most suitable. Generally the main targeted segment is that of the families, followed by - not mentioning the non-specified group of „everyone" - the sick people coming for treatments, then the segment of elderly visitors, the foreigners, and the retired people, pensioners. With the only exception of Hévíz all the other settlements focus on the target groups looking for recreation and relaxation. For Hévíz the primary target group is the sick and the elderly people, emphasising medical tourism as the main activity.

Table 9 Main target groups by settlements - What kind of tourists are expected?

\begin{tabular}{|r|c|c|c|c|c|c|c|c|}
\hline \% of respondents & Hévíz & $\begin{array}{c}\text { Kehida- } \\
\text { kustány }\end{array}$ & Lenti & $\begin{array}{c}\text { Zala- } \\
\text { karos }\end{array}$ & Marcali & Siklós & $\begin{array}{c}\text { Total } \\
\text { (number, \%) }\end{array}$ & Rank \\
\hline Families & 21.1 & 60.0 & 27.3 & 85.0 & 35.0 & 30.0 & 46 & $\mathbf{1}$ \\
\hline Everyone & 15.8 & 10.0 & 27.3 & 10.0 & 25.0 & 30.0 & 18 & $\mathbf{2}$ \\
\hline $\begin{array}{r}\text { Sick people for } \\
\text { treatment }\end{array}$ & 47.4 & 15.0 & 9.1 & 20.0 & 0.0 & 0.0 & 17 & $\mathbf{3}$ \\
\hline Older peopIe & 36.8 & 5.0 & 9.1 & 20.0 & 5.0 & 20.0 & 16 & $\mathbf{4}$ \\
\hline Foreign visitors & 21.1 & 5.0 & 9.1 & 10.0 & 15.0 & 20.0 & 13 & $\mathbf{5}$ \\
\hline
\end{tabular}


Table 9 (continued)

\begin{tabular}{|r|c|c|c|c|c|c|c|c|}
\hline \% of respondents & Hévíz & $\begin{array}{c}\text { Kehida- } \\
\text { kustány }\end{array}$ & Lenti & $\begin{array}{c}\text { Zala- } \\
\text { karos }\end{array}$ & Marcali & Siklós & $\begin{array}{c}\text { Total } \\
\text { (number, \%) }\end{array}$ & Rank \\
\hline $\begin{array}{r}\text { Retired people, } \\
\text { pensioners }\end{array}$ & 0.0 & 15.0 & 27.3 & 5.0 & 25.0 & 0.0 & 12 & $\mathbf{6}$ \\
\hline Middle-aged people & 15.8 & 0.0 & 27.3 & 0.0 & 10.0 & 20.0 & 10 & $\mathbf{7}$ \\
\hline Young people & 15.8 & 5.0 & 18.2 & 10.0 & 0.0 & 10.0 & 9 & $\mathbf{8}$ \\
\hline Domestic tourists & 5.3 & 5.0 & 9.1 & 20.0 & 5.0 & 0.0 & 8 & $\mathbf{9}$ \\
\hline All respondents, \% & $\mathbf{1 0 0 . 0}$ & $\mathbf{1 0 0 . 0}$ & $\mathbf{1 0 0 . 0}$ & $\mathbf{1 0 0 . 0}$ & $\mathbf{1 0 0 . 0}$ & $\mathbf{1 0 0 . 0}$ & $\mathbf{1 0 0 . 0}$ & \\
\hline $\begin{array}{l}\text { All respondents, } \\
\text { number }\end{array}$ & $\mathbf{1 9}$ & $\mathbf{2 0}$ & $\mathbf{1 1}$ & $\mathbf{2 0}$ & $\mathbf{2 0}$ & $\mathbf{1 0}$ & $\mathbf{1 0 0}$ & \\
\hline
\end{tabular}

Note: each respondents might indicate more than one target groups, therefore the sum of columns may be larger than $100 \%$.

The evaluation also compared the distributions of responses by respondents' settlement and job status, but no significant differences were found. The only exception is the target group of pensioners, who were mentioned in higher proportions $(24-20 \%)$ by local population and by the representatives of the public sector (municipalities and the Tourinform bureaus and TDM organisations), than the other respondents. Significant differences were found among the settlements in the proportions of families, sick people and retired people, as main target groups. Families are the most preferred tourist segment in Kehidakustány and Zalakaros (above 50\% mentioned this group) and Hévíz does not focus on them (only 12\% mentioned them), while in the case of retired people the values of Hévíz and Siklós are much lower than the other settlements. The sick people coming for treatments are a specific targeted segment for Hévíz, 47\% of the respondents mentioned this segment, which is much higher than elsewhere (Tab. 9).

\section{I: Industry}

Respondents assessed tourism infrastructure and tourism superstructure by a 1 to 5 scale (1 indicated the worst opinion and 5 the best one). They were asked to evaluate food service, accommodation, transport and parking, shopping and entertainment and sports facilities. Altogether they were most satisfied with food service facilities, followed by accommodation, transport and parking, shopping opportunities and entertainment and sports facilities. Lenti and Marcali were different from the average about shopping opportunities, this facility was more satisfactory for respondents in these two towns, while respondents were much less satisfied here with availability of accommodation, than elsewhere. 
Detailed analysis showed (Tab. 10), that there are significant differences among settlements in terms of transport and parking, accommodation facilities, and shopping facilities, while all settlements showed similar values for entertainments and sports facilities (everywhere below 3.5) and food service facilities (everywhere above 3.5). The responses of Kehidakustány were nearly always more negative, while responses from Marcali and Lenti more positive than of the other settlements.

Table 10 Assessment of tourism infrastructure and superstructure by settlements

\begin{tabular}{|c|c|c|c|c|c|c|c|c|}
\hline & Hévíz & $\begin{array}{c}\text { Kehida- } \\
\text { kustány }\end{array}$ & Lenti & $\begin{array}{c}\text { Zala- } \\
\text { karos }\end{array}$ & Marcali & Siklós & $\begin{array}{c}\text { Average } \\
\text { of } \\
\text { feature }\end{array}$ & Rank \\
\hline Food service & 4.47 & 3.58 & 4.40 & 4.25 & 4.11 & 4.30 & $\mathbf{4 . 1 6}$ & 1 \\
\hline Accommodation & 4.68 & 4.00 & 3.60 & 4.70 & 3.42 & 4.10 & $\mathbf{4 . 1 3}$ & 2 \\
\hline Transport, parking & 4.11 & 3.47 & 4.20 & 4.60 & 4.37 & 3.70 & $\mathbf{4 . 1 0}$ & 3 \\
\hline Shopping opportunities & 3.58 & 2.37 & 4.30 & 3.00 & 4.00 & 3.90 & $\mathbf{3 . 4 1}$ & 4 \\
\hline Entertainments, sports & 3.47 & 2.42 & 3.00 & 3.35 & 2.53 & 2.80 & $\mathbf{2 . 9 4}$ & 5 \\
\hline average of settlement & $\mathbf{4 . 0 6}$ & $\mathbf{3 . 1 7}$ & $\mathbf{3 . 9 0}$ & $\mathbf{3 . 9 8}$ & $\mathbf{3 . 6 8}$ & $\mathbf{3 . 7 6}$ & $\mathbf{3 . 7 5}$ & \\
\hline
\end{tabular}

\section{C: Community}

The term , community ${ }^{6}$ refers to local inhabitants, and public organisations working for the improvement of the quality of life in the destination. Therefore besides local inhabitants the activities of the public sector - municipalities and TDM organisations, or Touriform bureaus - are assessed.

Respondents were asked to assess the activities of the TDM organisations. They were most satisfied with the interest representation of the profession and the training activities carried out by these organisations, followed by the complex tourism development activities, and the targeted promotional actions, and the coordination of the stakeholders' cooperation. All these aspects were assessed as very good, with scores above 4 on the 1to-5 scale. Respondents were the least satisfied with the ability of TDM organisations to attract investors, the average level of satisfaction was 3.71. There are striking differences between the settlements, the performance in Hévíz and Zalakaros are outstanding, while the poorest performance was measured in Kehidakustány. Siklós has no results due to respondent disinclination (Fig. 5).

The accommodation and food service providers are completely satisfied with nearly all aspects, representatives of the spas valued all the activities of the organisation below the good level, and local inhabitants considered only two aspect - the targeted promotional 
actions and the professional interest representation - good. The employees of the Tourinform bureaus and TDM organisations are much less critical about their own activities, theirs scores are at least good for all apects, except one. This exception is the ability to attract investors, here the respondents valued their own activities as medium to good (Fig. 6).

Figure 5 Opinions on the performance of TDM organisations (1 to 5 scale), by settlements

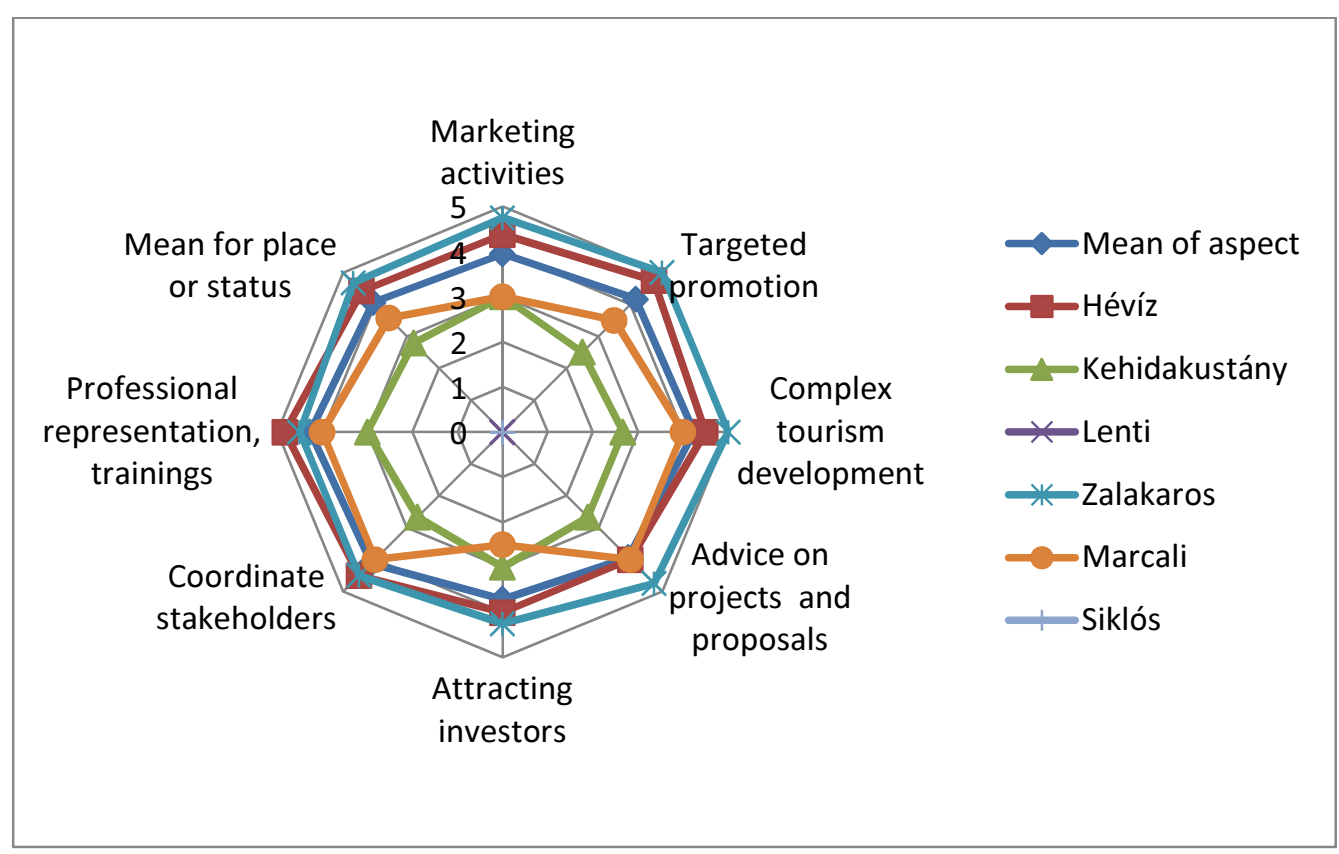

Figure 6 Opinions on the performance of TDM organisations (1 to 5 scale), by job status

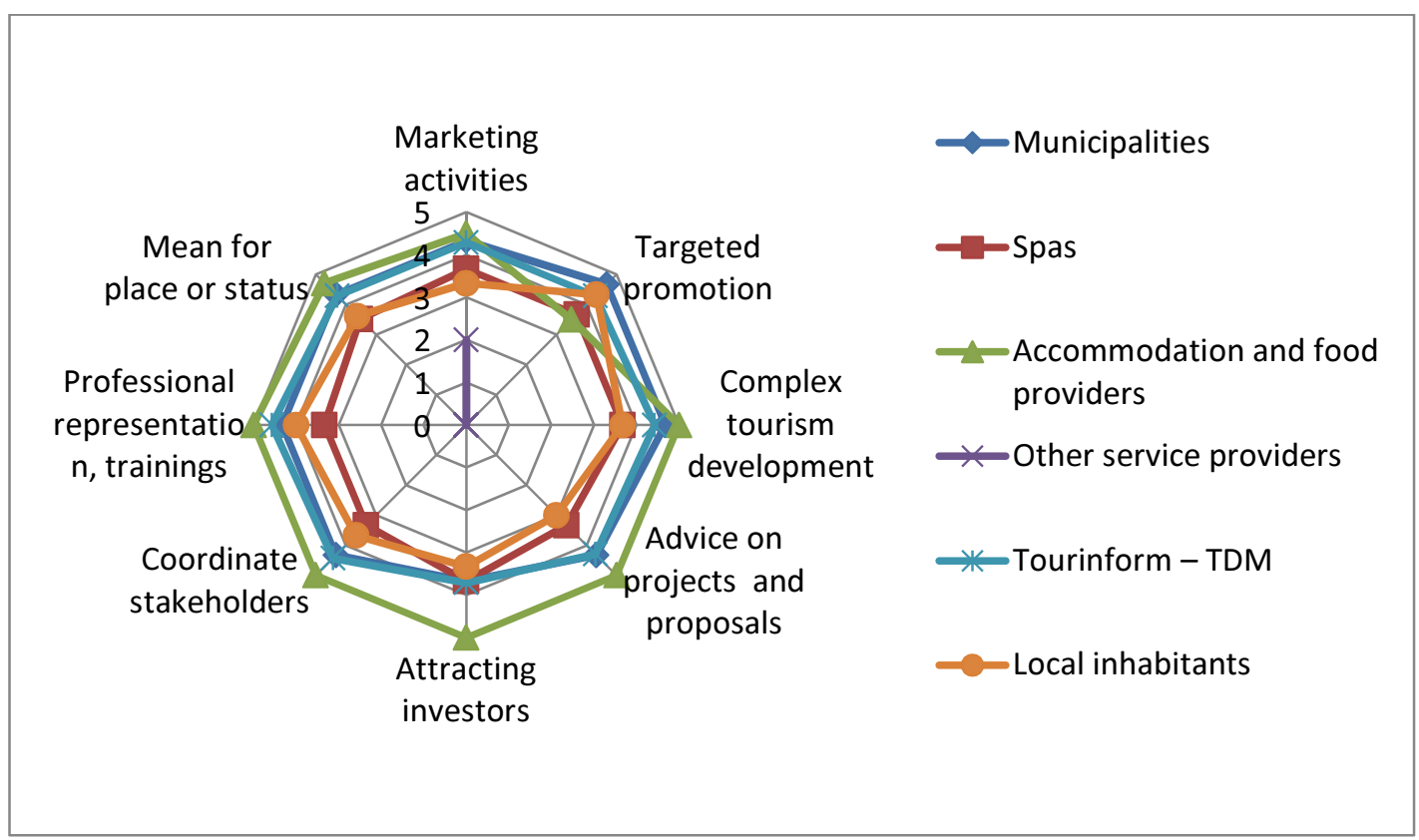


Respondents considered marketing activities to be the most important function of a health tourism TDM organisation, it was mentioned by $11 \%$ of the 100 respondents. The need for marketing activities were mentioned more often than the average by the employees of municipalities, spas, and of Tourinform bureaus and TDM organisations. The representatives of accommodation and food service providers, and local inhabitants have hardly given any answer to the question, and no answer was received from other service providers. Other tasks were mentioned by one or two respondents only, which is not enough to draw conclusions.

Satisfaction with the TDM organisations is also well represented by the inclination of respondents to join these organisations. More than half of the responents (57\%) expressed disinclination to join a TDM organisation. Refusal was extremely high (two thirds to three-quarters of respondents) among local inhabitants, and representatives of municipalities and of other service providers. The majority of other actors (spas, Tourinform bureaus and TDM organisations) gave positive answers to the question. Comparing the settlements Marcali differs from the rest, because here the majority $(60 \%)$ was inclined to join a TDM organisation.

Figure 7 Inclination to join a TDM organisation, by settlements and by respondents' job status

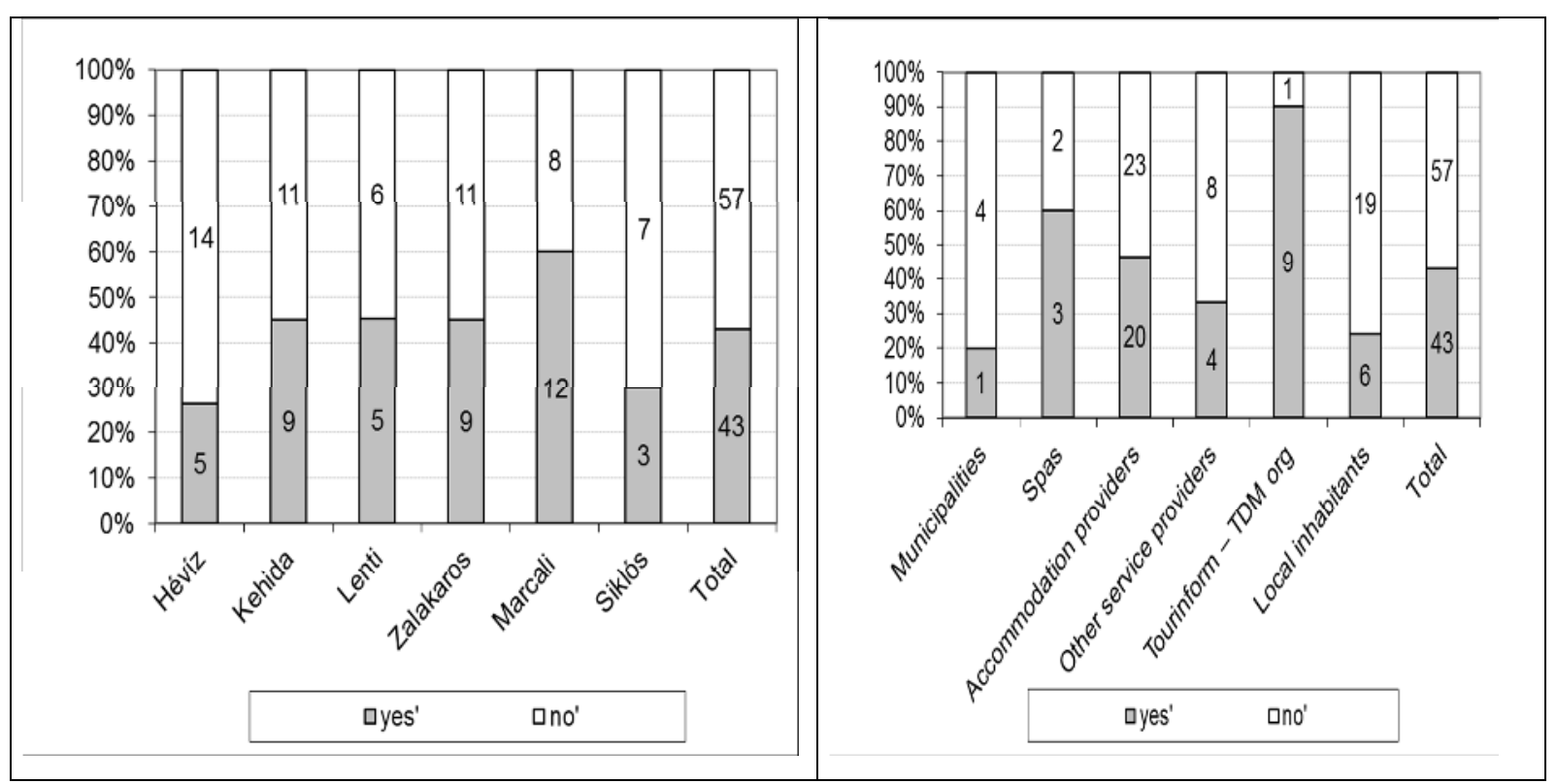




\section{CONCLUSION}

Based on the above results the key components of Climpson's VICE model (Climpson, 2008) are specified below for health tourism destinations. This model sums up the components that a successful, sustainable and competitive destination should incorporate and coordinate. The four factors introduced earlier, comprises the demand side (V visitors), the supply service providers (I - tourism industry), the local people (C Community) and the environment (E) as the basis for the supplied tourism package.

Figure 8 The application of the VICE model for health tourism destinations

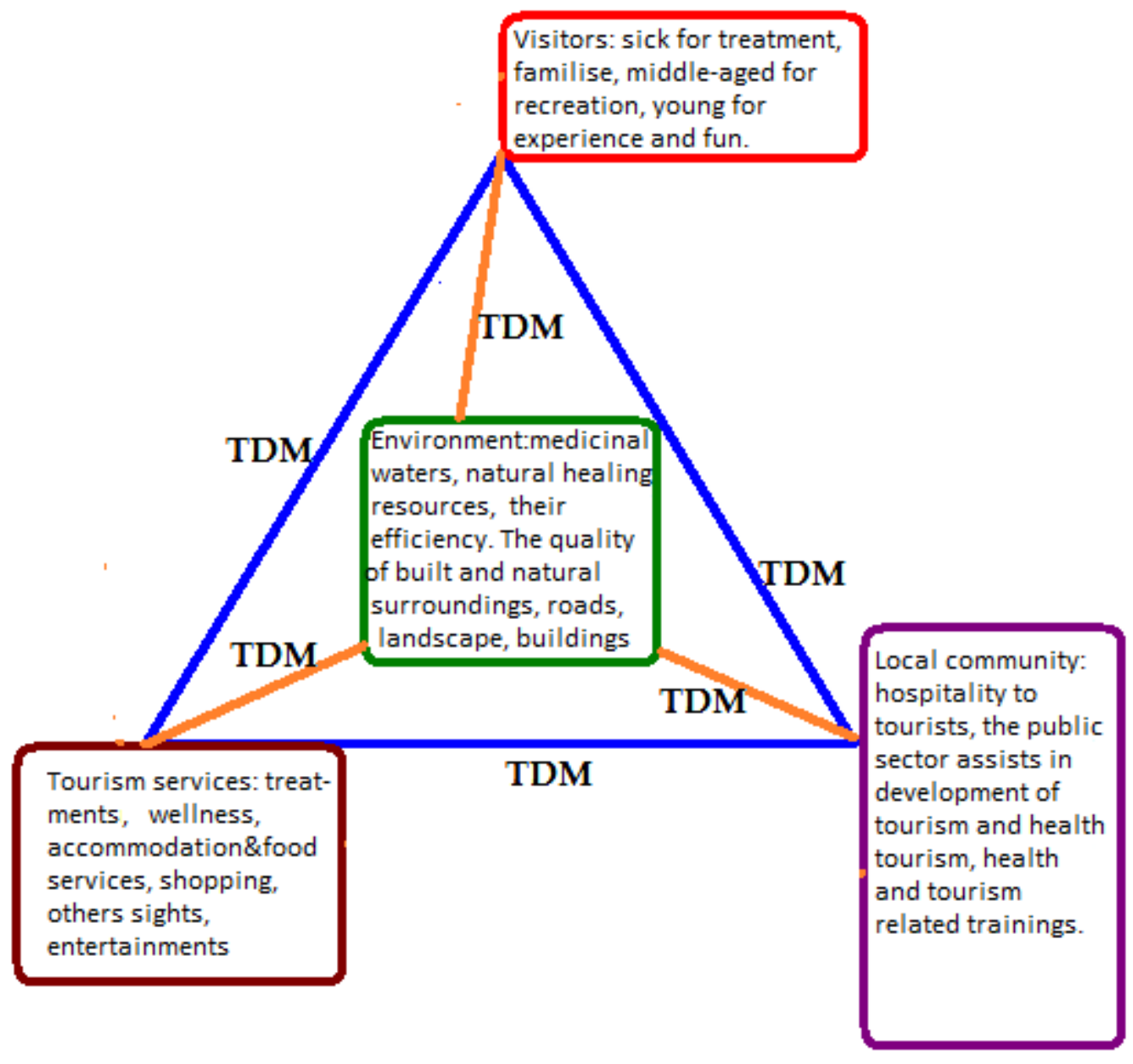

For health tourism destinations the four components, shown in Fig. 8, may be specified as:

- $V$ : the targeted tourist segments. The primarily targeted segment is the sick people coming to the destination to receive treatments, the secondary targeted segment is those coming for prevention, and the families requiring recreation, those looking for 
relaxation, and staying young and healthy, as well as young peoples who come for fun and exciting experiences.

- I: the providers of special health tourism services, eg. spas, health hotels, wellness hotels, and fun spas, as well as the wide range of accommodation facilities, other entertainment facilities, restaurants (especially those specialising in healthy food and health-conscious gastronomy). Besides health tourism facilities the availability of general tourism services is also important, including providers of cultural events, shopping opportunities, because the visitors cannot spend all their time attending treatments, but would require other entertainments and experiences. As the most important tourism product is the treatment needed for prevention and cure, it is crucial to involve not only tourism service providers, but health care institutions, too (hospital, spa hospital, other healthcare establishments and medical services). Healthrelated services require the human resources with relevant qualitfications - i.e. physicians, therapists - but the availability of the relevant technology, too. The level of knowledge of Hungarian medical staff is outstanding by international standards. The marketability of health tourism may be improved by the increasing visibility of medical services. Therefore, in the marketing of tourism products the medical efficiency of therapies should be communicated supported by documentation and medical evidence.

- C: the local community, public actors: the hospitality of local inhabitants, their positive attitude to tourists coming to the destination is a crucial requirement. The developments of public infrastructure should respond the needs of local population and of health tourists alike, finding the common benefit of both groups. The development of healthcare services is beneficial for the local population, and the income-generating positive impacts of health tourism will be felt by inhabitants, by the increasing financial resources received by the local governments, the infrastructural improvements, the better transport facilities, better services, etc. Some minor negative impact may be felt by crowding due to large volumes of tourists, the slight price increases due to increasing demand, although the positive impacts will usually compensate for these. Generally speaking, the quality of life is generally better than the average in spa towns and villages, tourism destinations, and the multiplier effect of tourism is experienced everywhere. Consultations between the local population, the municipalities and the tourism stakeholders will lead to the 
general understanding of the tourism product as a commonly owned valuable asset of the destination, and people will identify with it regardless of their actual employment area.

- E: among environmental features the first place is given to medicinal and thermal waters, but clear air, pleasant microclimatic conditions and rich natural vegetation are also important endowments. In health resorts the quiet, peaceful environment is also a compulsory requirement, and the built environment should be maintained in good conditions, including renovation of buildings, and reconstruction of the road network. Favourable economic environment, i.e. the favourable business conditions, good employment possibilities are important not only for health tourism, but for tourism in general. For qualified employees the educational system, the vocational trainings available in the area should be strong in the healthcare and health tourism fields. Transport facilities, accessibility of buildings should be a priority, and the volume of motorised transport should be decreased or restricted zones with no car entrance should be estalished, to decrease pollution. For this purpose cycle tracks and walking paths should be developed and public transport improved.

\section{SUMMARY}

Tourism destination management (TDM) is a popular catchword of current tourism research. A research, cofinanced by the European Union through the Hungary-Croatia IPA Cross-border Co-operation Programme, within the project 'Health \&Rural Tourism DM Model' (project no.: HUHR/1101/2.1.3/0006), was carried out in 2013 to analyse the specialities of TDM in health tourism destinations, the physical and human resources of such destinations, aspects of sustainability and competitiveness, the main factors of success.

The motivation of the research was to find the core components of health tourism destination management, considering the fact, that the core product they offer is a complex experience, which incorporates attractions and entertainment, accommodation and food, accessibility and local transport, hospitality and friendly attitude of local people. Such a complex supply requires the close cooperation of businesses working in the tourism industry, the municipalities and public authorities as well as local inhabitants. The special attractions of the area should be treated with great care to guarantee sustainability, while development plans should pay attention to the interests of all stakeholders, including tourists.

Primary data were collected by surveys and interviews carried out in six spa towns of Western Hungary. Assessing the traits of tourism service providers, the natural assets, the local community and the targeted tourist segments a general model of health tourism destinations was outlined by the four components of the well-known VICE model.

$V:$ the targeted tourist segments. The primarily targeted segment is the sick people coming to the destination to receive treatments, the secondary targeted segment is those coming for prevention, and the families requiring recreation, those looking for relaxation, and staying young and healthy, as well as young peoples who come for fun and exciting experiences.

I: The providers of special health tourism services, eg. spas, health hotels, wellness hotels, and fun spas, as well as the wide range of accommodation facilities, other entertainment facilities, restaurants (especially 
those specialising in healthy food and health-conscious gastronomy). Besides health tourism facilities the availability of general tourism services is also important, including providers of cultural events, shopping opportunities. It is crucial to involve not only tourism service providers, but health care institutions, and staff with relevant qualitfications.

C: the local community, public actors: the hospitality of local inhabitants, their positive attitude to tourists coming to the destination is a crucial requirement. The developments of public infrastructure and health care services should respond the needs of local population and of health tourists alike, finding the common benefit of both groups.

E: among environmental features the first place is given to medicinal and thermal waters, but clear air, pleasant microclimatic conditions and rich natural vegetation are also important endowments. In health resorts the quiet, peaceful environment is also a compulsory requirement, and the built environment should be maintained in good conditions, including renovation of buildings, and reconstruction of the road network. Favourable economic environment, i.e. the favourable business conditions, good employment possibilities are important not only for health tourism, but for tourism in general. For qualified employees the educational system, the vocational trainings available in the area should be strong in the healthcare and health tourism fields. Transport facilities, accessibility of buildings should be a priority, and the volume of motorised transport should be decreased or restricted zones with no car entrance should be estalished, to decrease pollution. For this purpose cycle tracks and walking paths should be developed and public transport improved.

\section{REFERENCES}

Aubert, A., Albert-Tóth, A., Bakos, R., Gelány, N., Gyurácz-Németh, P., Huszti, Z., Kalmárné Rimóczi, Cs., Kátay, Á., Kóródi, M., Kovács, T., Máté, A., Németh, M., Pichler, J., Raffay, Á. \& Rátz, T. (2011). Turizmus-menedzsment. Pécs: Pécsi Tudományegyetem (in Hungarian)

Bacsi, Zs.; Kovács, E. ; Lőke, Zs. (2011). Spa successes and challenges in Transdanubia, Hungary - Results of a survey in three spa towns. Deturope, 4 (1), p. 24-43.

Boros Szilvia -Mondok Anita - Várhelyi Tamás (2012). Az egészségturizmus szolgáltatásai és menedzsmentje. Szolnoki Főiskola, Szolnok (in Hungarian)

Climpson, A. (2008, February). Sustainable Destination Management: the VICE model. Tourism Insight. Retrieved November 10, 2013, from: http://www.insights.org.uk/ articleitem.aspx?title $=$ Sustainable + Destination + Management $\% 3 \mathrm{~A}+$ the $+\mathrm{VICE}+$ mode 1

Dwyer, Larry and Kim, Chulwon (2004). Destination Competitiveness: A Model and Determinants . Current Issues in Tourism, 1-12.

Enright, M. J. \& Newton, J. (2006). Tourism destination competitiveness: A quantitative approach. Tourism Management, 25, 777-788.

Kontaktia (2011). A hazai TDM szervezetek ügyfélkezelése. Kutatási elemzés. Retrieved from: http://kontaktia.hu/sites/default/files/kepek/box/tudastar/Hazai-TDMszervezetek-marketing-kutatasi-elemzes.pdf (in Hungarian)

Kovács, E.; Bacsi, Zs.; Lőke, Zs. (2011b). Healing - Pleasure - Competitiveness: Empirical Assessment of the Spa Settlements in Baranya, Somogy and Zala counties. In: Kovács, E. ; Bacsi, Zs.; Lőke, Zs. (eds, 2011). The Role of Health Tourism in Improving the Competitiveness of the Croatian-Hungarian Border Region (pp. 3976). Balatoni Integrációs Közhasznú Nonprofit Kft, Siófok (Hungary)

KSH (2013). A gyógyturizmusban érintett települések Magyarországon. Retrieved from: http://www.ksh.hu_(in Hungarian) 
Lengyel Márton (1994/2004). A turizmus általános elmélete. Budapest: Heller Farkas Főiskola / KIT Képzőművészeti Kiadó. (in Hungarian)

Lengyel Márton (ed., 2008). TDM Müködési Kézikönyv. Budapest: Heller Farkas Föiskola. (in Hungarian)

Miller, W.J.(2004). Statistics and Measurement Using the Free OpenStat Package. Retrieved from: http://www. statprograms4u.com

Miller, W.J.(2013). OpenStat Reference Manual. Retrieved from: http://www. statprograms4u.com

Nyírádi, Ágnes \&Semsei, Sándor (ed, 2007). Balatoni TDM-füzetek. Siófok: Balatoni Integrációs és Fejlesztési Ügynökség Kht. (in Hungarian)

Panyor Ágota, Győriné Kiss Erika, Herbály Katalin (szerk, 2011). Bevezetés a desztináció-menedzsmentbe. Egyetemi tankönyv. Keszthely: Pannon Egyetem. (in Hungarian)

Papp Zsófia (2012). A turisztikai desztinációk versenyképessége - hogyan mérjük? Modellek és módszerek áttekintése. In: Bajmócy Zoltán - Lengyel Imre - Málovics György (szerk.). Regionális innovációs képesség, versenyképesség és fenntarthatóság. (pp 225-238). Szeged: JATEPress. (in Hungarian)

Pike, S (2008). Destination Marketing - An Integrated Marketing Communication Approach. Amsterdam-Heidelberg-New York: Elsevier - Butterworth-Heinemann.

Porter, M.E. (1990). The competitive advantage of nations, New York:The Free Press.

Ritchie, J. R. B. \& Crouch, G. (2003). The Competitive Destination - A Sustainable Tourism Perspective. Oxford: CABI Publishing.

UNWTO (2007). A Practical Guide to Tourism Destination Management. Madrid: WTO. Wikitravel - Zala megye (2013). www.wikitravel.org/Zala_megye. Retrieved: 16 Oct 2013. (in Hungarian) 